\title{
FIRST RECORD OF LONGIDORELLA XENURA AND ORIVERUTUS PARVUS (NEMATODA: NODIIDAE) IN CUC PHUONG NATIONAL PARK, VIETNAM
}

\author{
Nguyen Thi Anh Duong ${ }^{1 *}$, Vu Thi Thanh Tam ${ }^{1}$, Reyes Peña-Santiago ${ }^{2}$ \\ ${ }^{1}$ Institute of Ecology and Biological Resources, VAST, *nad2807@yahoo.com \\ ${ }^{2}$ University of Jaén, Spain
}

\begin{abstract}
Longidorella xenura and Oriverutus parvus from Cuc Phuong National Park are described and illustrated for the first time in Vietnam. Longidorella xenura species is characterized by its small body $0.72 \mathrm{~mm}$ long; lip region continuous; odontostyle typical of the genus, slightly arched; odontophore linear, rod-like; female genital system didelphic-amphidelphic; tail conical elongated with finely rounded tip. Oriverutus parvus species is characterized by its body $0.64-0.68 \mathrm{~mm}$ long; lip region slightly angular, offset by depression or weak constriction; lips moderately amalgamated with protruding papillae but not typically lobe-like; odontostyle moderately robust; odontophore rod-like; female genital system didelphicamphidelphic; tail conical with pointed tip.
\end{abstract}

Keywords: Dorylaimida, Nordiidae, Longidorella xenura, Oriverutus parvus, morphology, Vietnam.

\section{INTRODUCTION}

Nordiidae is poorly known dorylaimid family of free-living nematodes in Vietnam, with only one described species as Actinolaimoides angolensis (Andrássy, 1963) Siddiqi, 1982, which was collected from Cuc Phuong National Park in northern Vietnam by Andrássy (1970). In this paper, two species of Longidorella xenura and Oriverutus parvus in this area were recorded for the first time in Vietnam. Based on high resolution microphotographs, our study allows having better characterization of those species.

\section{MATERIALS AND METHODS}

Soil samples were collected from a pristine tropical forest in Cuc Phuong national park, Vietnam. Nematodes were extracted from soil sample by modified Baermann funnel technique [3], killed by heat, fixed in formaldehyde $4 \%$, transferred to anhydrous glycerol according to Siddiqi (1964) [10], and mounted on glass slides for their handling. Specimens were photographed with a Nikon Eclipse 80i microscope and a Nikon DS digital camera. Raw photographs were edited using Adobe ${ }^{\circledR}$ Photoshop® CS.

\section{RESULTS AND DISCUSSION}

Redescription

\section{Longidorella xenura Khan \& Siddiqi, 1963 (Fig. 1)}

Syn.: Enchodorella xenura (Khan \& Siddiqi, 1963) Siddiqi, 1964; Nordia thornei Jairajpuri \& Siddiqi, 1964 [syn. by Andrássy (1966)]; Longidorella suviswa Patil \& Khan, 1982 [syn. by Siddiqi (2007)]; Longidorella xesua Saha, Lal \& Singh, 2002 [syn. by Siddiqi (2007)].

Material examined: Two females, in a very good condition.

Female: Moderately slender nematodes of small size, $0.72 \mathrm{~mm}$ long. Body cylindrical, tapering towards both extremities, but more so towards posterior end as tail is conical. Habitus curved ventrad after fixation to an open ' $\mathrm{C}$ ' shape. Cuticle $2.0 \mu \mathrm{m}$ thick in anterior region, $3.0 \mu \mathrm{m}$ in mid-body and 4.0-4.5 $\mu \mathrm{m}$ on tail, nearly smooth throughout the body, although visibly irregular at ventral side of caudal region (see figure 1). Lateral chord 5.5-7.0 $\mu \mathrm{m}$ wide at mid-body, occupying about one-fourth (23\%) of corresponding body diameter. Lip region continuous, 2.4 as broad as high and approximately one-fifth (20\%) of body diameter at neck base. Amphid fovea cup-shaped, its aperture 4-6 $\mu \mathrm{m}$ or about three-fourths (70\%) of lip region diameter. Cheilostom cylindrical, lacking any differentiation. Odontostyle typical of the genus, slightly arched, 7.2 times as long as lip region width and about $6.0 \%$ of total body length. 

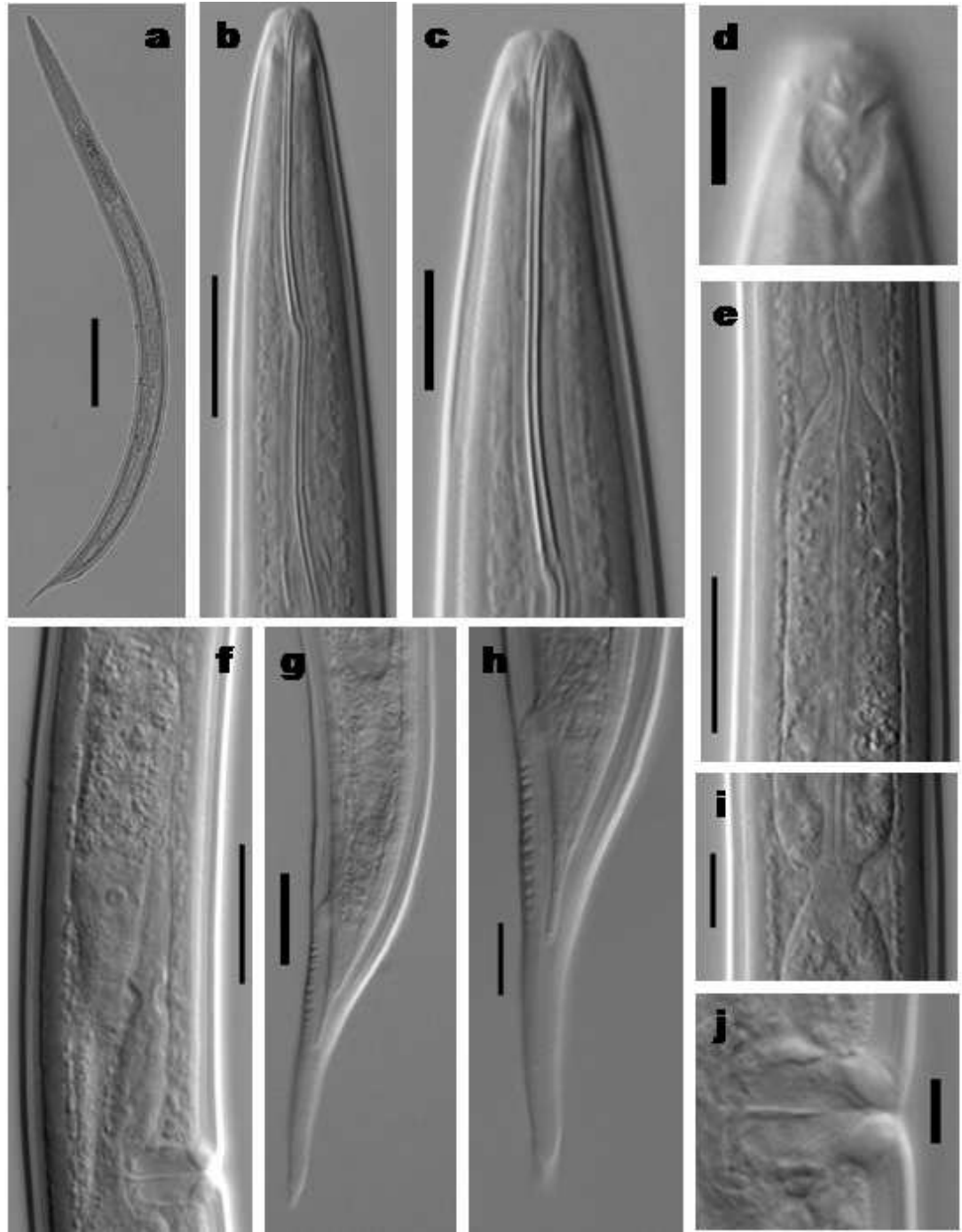

Figure 1. Longidorella xenura Khan \& Siddiqi, 1963 (female, LM)

a. Entire; b, c. Anterior region in median view; d. Lip region in surface view; e. Pharyngeal enlargement; $f$. Anterior genital branch; g. Posterior body region; h. Caudal region; i. Pharyngo-intestinal junction; j. Vagina. (Scale bars: $\mathrm{a}=100 \mu \mathrm{m} ; \mathrm{b}, \mathrm{e}-\mathrm{g}=20 \mu \mathrm{m} ; \mathrm{c}, \mathrm{h}, \mathrm{i}=10 \mu \mathrm{m} ; \mathrm{d}, \mathrm{j}=5 \mu \mathrm{m}$ ).

Guiding ring at $25 \mu \mathrm{m}$ from anterior end. Odontophore linear, rod-like as long as odontostyle. Anterior region of pharynx slender and poorly muscular, enlarging abruptly and separate from basal expansion by a short and weak narrowing; basal expansion 4.5-5.8 times as long as broad, 2.7-3.2 times as long as body diameter, occupying up to two-fifths (38-39\%) of total neck length; pharyngeal gland nuclei located as follows: $\mathrm{DO}=63-64, \mathrm{DN}=67-68$,
$\mathrm{S}_{1} \mathrm{~N}_{1}=81, \mathrm{~S}_{1} \mathrm{~N}_{2}=88 \quad \mathrm{~S}_{2} \mathrm{~N}=93-94$. Cardia conical, $10 \times 6.0 \mu \mathrm{m}$. Genital system didelphicamphidelphic, with both branches equally and well developed, the anterior branch is $80-87 \mu \mathrm{m}$ and the posterior branch is $80-83 \mu \mathrm{m}$ long. Ovaries well developed, often surpassing the sphincter level, the anterior part is $68-76 \mu \mathrm{m}$ and the posterior part is $56-60 \mu \mathrm{m}$ long, with oocytes arranged in a single row. Oviduct quite short 35-38 $\mu \mathrm{m}$ long or 1.1-1.2 times 
corresponding body diameter, consisting of slender part with prismatic cells and a very poorly developed pars dilatata. A distinct sphincter separates oviduct and uterus. Uterus a simple tube, 19-25 $\mu \mathrm{m}$ long or 0.6-0.7 times corresponding body diameter. Vagina extending inwards $13 \mu \mathrm{m}$ or about two-fifths $(37-43 \%)$ of body diameter: pars proximalis as long as broad, 7-9 × 7-8 $\mu \mathrm{m}$, with somewhat sigmoid walls and surrounded by weak musculature; pars refringens with (in lateral view) two close pieces measuring $3 \times 4 \mu \mathrm{m}$ and with a combined width of $8 \mu \mathrm{m}$; and pars distalis very short.
Vulva a post-equatorial, transverse slit. Prerectum about 1.7 time and rectum approximately 0.7-1.1 time of anal body diameter long. Tail conical elongated with finely rounded tip; ventrally nearly straight, dorsally first convex and then somewhat concave; the cuticle at the anterior ventral side of tail shows distinct irregularities consisting of coarse striation and or weak wrinkles; hyaline portion $35 \mu \mathrm{m}$ long or about one-half of tail length; caudal pores two pairs, sub-dorsal, at the middle of tail.

Male: Not found.

Table 1. Morphometric data of Longidorella xenura Khan \& Siddiqi, 1963, All measurements are in $\mu \mathrm{m}$ except ratios $\mathrm{a}, \mathrm{b}, \mathrm{c}, \mathrm{c}^{\prime}$ and $\mathrm{L}$ in $\mathrm{mm}$.

\begin{tabular}{|l|c|c|}
\hline \multirow{2}{*}{ Neference } & \multicolumn{2}{|c|}{ Longidorella xenura } \\
\cline { 2 - 3 } & India & Vietnam \\
\cline { 2 - 3 } & Khan \& Siddiqi (1963) & Present paper \\
\cline { 2 - 3 } & Type material & Paratype \\
\hline \multirow{2}{*}{$\mathrm{L}$} & $? ?$ q & 299 \\
\hline $\mathrm{a}$ & $0.69-0.75$ & $0.72,0.72$ \\
\hline $\mathrm{b}$ & $22-24$ & $20.7,24.1$ \\
\hline $\mathrm{c}$ & $2.8-2.9$ & $3.0,3.0$ \\
\hline V & $?$ & $9.3,11.1$ \\
\hline c' & $59-61$ & 57,59 \\
\hline Lip region diameter & $?$ & $3.6,4.3$ \\
\hline Odontostyle length & & $6.0,6.0$ \\
\hline Odontophore length & 44 & 43,43 \\
\hline Neck length & $?$ & 40,45 \\
\hline Pharyngeal expansion length & $?$ & 239,240 \\
\hline Body diameter - neck base & $?$ & 90,93 \\
\hline Body diameter - mid-body & $?$ & 29,33 \\
\hline Body diameter - anus & $?$ & 30,35 \\
\hline Prerectum length & $?$ & 18,18 \\
\hline Rectum length & $?$ & 30,30 \\
\hline Tail length & $?$ & 12,20 \\
\hline
\end{tabular}

?. no information.

\section{Remarks}

The two Vietnamese females perfectly fits with the previous ones (Khan \& Siddiqi, 1963 [6]; Loof, 1964 [7]; Jairajpuri \& Siddiqi, 1964 [5], as Nordia thornei; Jairajpuri \& Hooper, 1969 [4], Suryawanshi, 1971 [12]; Patil \&
Khan, 1982 [8], as Longidorella suviswa; Saha et al., 2002 [9], as L. xesua), although new morphological details as well as morphometrics are herein provided, especially those referring to genital system. It is remarkable that pars refringens vaginae are well developed in the two specimens examined. 
Longidorella xenura is only known to occur in tropical areas so far, since it has been repeatedly reported from India, also from Venezuela (Loof, 1964) and Cameroon (Siddiqi, 2007) [11], and now from Vietnam.
Oriverutus parvus Ahmad \& Araki, 2002 (Fig. 2)

Material examined: Two females, in acceptable condition.
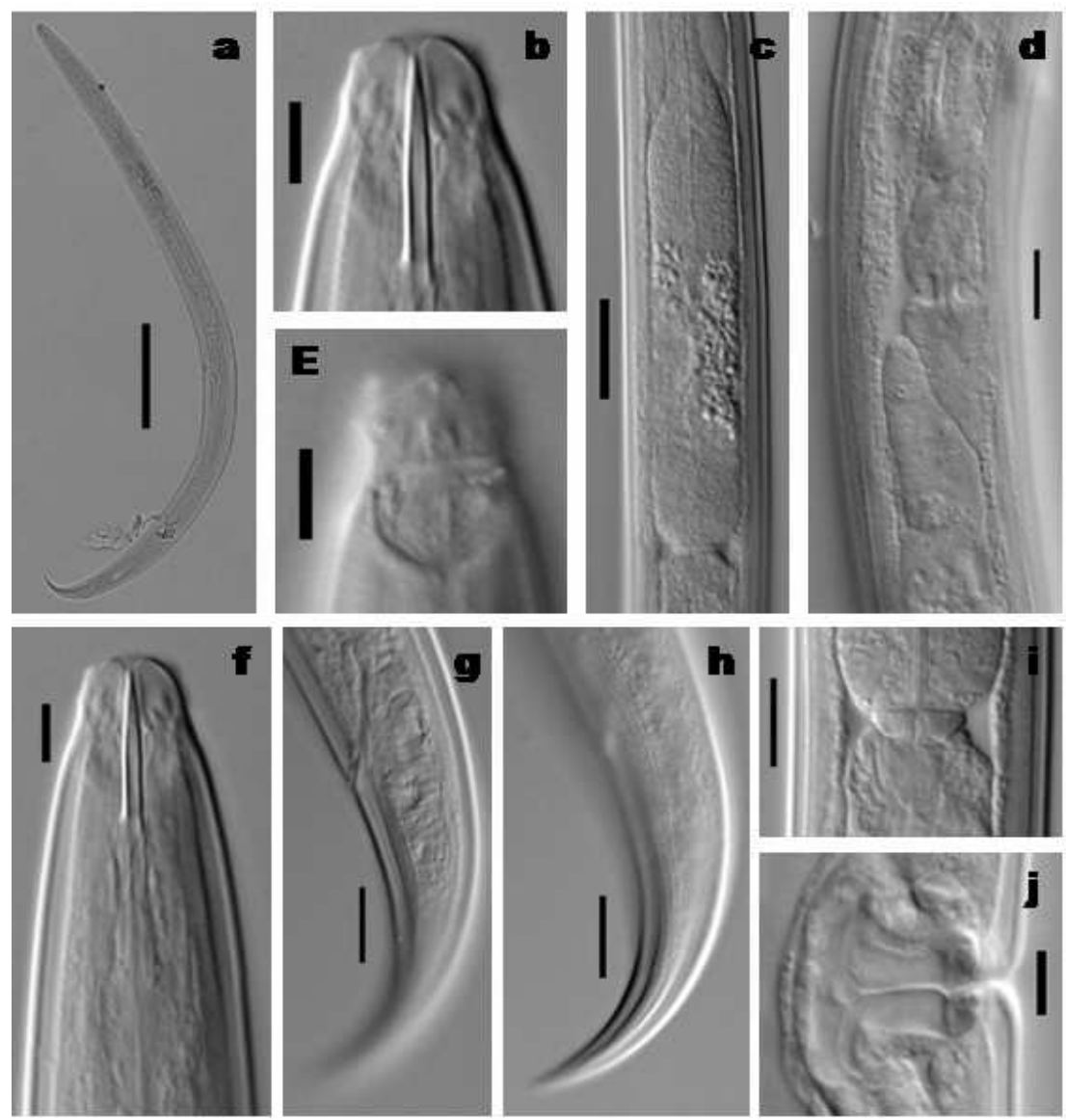

Figure 2. Oriverutus parvus Ahmad \& Araki, 2002 (female, LM).

a. Female, entire; b, f. Anterior region in median view; c. Pharyngeal expansion; d. Female, posterior genital branch; g, h. Caudal region; i. Pharyngo-intestinal junction; j. Vagina. (Scale bars: $a=100 \mu \mathrm{m} ; \mathrm{b}, \mathrm{e}, \mathrm{f}, \mathrm{j}=5 \mu \mathrm{m} ; \mathrm{c}=20 \mu \mathrm{m} ; \mathrm{d}, \mathrm{g}, \mathrm{h}, \mathrm{i}=10 \mu \mathrm{m}$ ).

Female: Moderately slender nematodes of small size, 0.64-0.68 mm long. Habitus after fixation curved ventrad, C-shaped. Body cylindrical, tapering towards both ends, but more so posteriorly due to conical tail. Cuticle $2.0 \mu \mathrm{m}$ thick in anterior region, $2.5 \mu \mathrm{m}$ at mid-body and $2.5 \mu \mathrm{m}$ on dorsal region of tail; outer layer with very fine transverse striation and thinner than inner one. Lateral chord $7.0 \mu \mathrm{m}$ wide or occupying one-fifth (23\%) of mid-body diameter, lacking any particular differentiation. Body pores obscure in material examined. Lip region slightly angular, offset by depression or weak constriction, 1.9 times as wide as high, and about one-third of body diameter at neck base; lips moderately rather amalgamated, with protruding papillae but not typically lobe-like. Amphid fovea cup-shaped, its aperture occupying $7.0 \mu \mathrm{m}$ or about two-thirds of lip region diameter. Cheilostom almost cylindrical, 
with no special differentiation. Odontostyle moderately robust, approximately 8.5 times as long as wide, 1.2-1.4 times longer than lip region diameter or $1.68 \%$ of total body length; aperture about one-fourth of total length. Odontophore 1.3-1.5 times as long as odontostyle, rod-like. Guiding ring simple, located at 5.0-5.5 $\mu \mathrm{m}$ or 0.6-0.7 lip region diameter from anterior end. Pharynx consisting of a slender muscular anterior portion enlarging gradually, pharyngeal expansion 4.7 times as long as broad and 2.7-2.8 corresponding boy diameter long, occupying about two-fifths (40\%) of total neck length. Cardia short, with three well developed cardia glands. Genital system didelphic-amphidelphic, with both branches equally and well developed, anterior branch is $105 \mu \mathrm{m}$ and posterior branch is $100 \mu \mathrm{m}$ long; ovaries large, the anterior $60 \mu \mathrm{m}$ and the posterior $66 \mu \mathrm{m}$ reaching level of sphincter, and with oocytes first in two or more rows, then in one row; oviduct short, the anterior $45 \mu \mathrm{m}$ and the posterior $50 \mu \mathrm{m}$ or 1.6 body diameter long, consisting of a slender portion with prismatic cells and a moderately developed pars dilatata with distinct lumen; sphincter well marked between oviduct and uterus; uterus a simple tube-like structure, 30-32 $\mu \mathrm{m}$ long or as long as body diameter; vagina extending inwards $13.0 \mu \mathrm{m}$ or about two-fifths $(40 \%)$ of body diameter: pars proximalis wider than long, $10.0 \mu \mathrm{m} \times 8.0 \mu \mathrm{m}$, with convergent walls and enveloped by weak circular musculature, pars refrigens with (in lateral view) two drop-shaped sclerotizations, as long as wide, 3.0-4.0 $\times 3.0$ $\mu \mathrm{m}$, and with a combined width of 7.0-8.0 $\mu \mathrm{m}$, and pars distalis short, $2.0 \mu \mathrm{m}$ long; vulva a slightly post-equatorial transverse slit. Prerectum about 2.5 time and rectum is 1.5 time of anal body diameter long. Tail conical with pointed tip, regularly curved ventrad; hyaline portion very short; caudal pores two pairs, at the posterior half of tail, one subdorsal, another subventral.

Male: Unknown.

Table 2. Morphometric data of Oriverutus parvus Ahmad \& Araki, 2002. All measurements are in $\mu \mathrm{m}$ except ratios $\mathrm{a}, \mathrm{b}, \mathrm{c}, \mathrm{c}$ ' and $\mathrm{L}$, in $\mathrm{mm}$.

\begin{tabular}{|l|c|c|c|}
\hline \multirow{2}{*}{ Deference } & \multicolumn{3}{c|}{ Oriverutus parvus } \\
\cline { 2 - 4 } & \multicolumn{2}{|c|}{ Japan [1] } & Vietnam (Present paper) \\
\cline { 2 - 4 } & Holotype & Paratype & Paratype \\
\hline $\mathrm{n}$ & 19 & $2+9$ & 290 \\
\hline $\mathrm{a}$ & 0.69 & $0.66-0.72$ & $0.64,0.68$ \\
\hline $\mathrm{b}$ & 22 & $20-21$ & $20.7,22.1$ \\
\hline $\mathrm{c}$ & 3.2 & $3.2-3.2$ & $2.8,3.0$ \\
\hline V & 17.3 & $17.7-18.6$ & $12.8,13.7$ \\
\hline c' & 54 & 55 & $59.1,53.8$ \\
\hline Lip region diameter & 1.96 & $1.85-1.87$ & $3.1,3.1$ \\
\hline Odontostyle length & 10 & $10-11$ & $8.0,8.0$ \\
\hline Odontophore length & 13 & $13-14$ & $24,0,14.0$ \\
\hline Guiding ring from anterior end & 16.5 & $17-18$ & $5.0,5.5$ \\
\hline Neck length & 5.7 & 6.5 & 225,225 \\
\hline Pharyngeal expansion length & 206 & $205-222$ & 90,90 \\
\hline Body diameter - neck base & 81 & $83-84$ & 32,33 \\
\hline Body diameter - mid-body & $?$ & $?$ & 31,31 \\
\hline Body diameter - anus & $?$ & $?$ & 16,16 \\
\hline Prerectum length & $?$ & $?$ & 40,40 \\
\hline Rectum length & 45 & $40-48$ & 22,22 \\
\hline Tail length & 18 & $18-20$ & 50,50 \\
\hline
\end{tabular}

?. no information 


\section{Remarks}

The two specimens examined are morphometrically very similar to type specimens from Japan [1], although the tail is longer in Vietnamese specimens (50 vs 37-39, $c$ $=13-14$ vs $c=17-19, c^{\prime}=3.1$ vs $\left.c^{\prime}=1.8-2.4\right)$. Taking into account that only a few specimens (three and two, respectively) have been hitherto studied in both cases, they are tentatively regarded as belonging to the same species, although it might be different.

Ahmad (2007) [2] described four females from Singapore and identified them as $O$. parvus, but they are larger (body length 0.87 $0.97 \mathrm{~mm}$ ) and bear longer odontostyle (15-16 $\mu \mathrm{m})$. Hence this material might not be nonspecific with the previous one. This species is reported for the first time in Vietnam.

\section{REFERENCES}

1. Ahmad W., Araki M., 2002. Two new and a known species of the genus Oriverutus Siddiqi, 1971 (Nematoda: Dorylaimida) from Japan. Japanese Journal of Nematology, 32: 31-44.

2. Ahmad W., 2007. New and known species of Dorylaimoidea (Nematoda: Dorylaimida) from Singapore. Nematology, 9: 215-229.

3. Baermann G., 1917. Eine einfache Methode zur Auffindung von Ankylostomum (Nematoden) Larven in Erdproben. Geneesk. Tijdschr. Ned-Indië, 57: 131-137.

4. Jairajpuri M. S., Hopper D. J., 1969. The genus Longidorella Thorne (Nematoda). Nematologica, 15: 275-284.

5. Jairajpuri M. S., Siddiqi A. H., 1964. On a new nematode genus Nordia (Dorylaimoidea: Nordiinae n.subfam.) with remarks on the genus Longidorella Thorne,
1939. Proceedings of the helminthological Society of Washington, 31: 1-9.

6. Khan E., Siddiqi M. R., 1963. Criconema laterale n.sp. (Nematoda: Criconematidae) from Srinagar, Kashmir. Nematologica, 9: 584-586.

7. Loof P. A. A., 1964. Free-living and plantparasitic nematodes from Venezuela. Nematologica, 10: 201-300.

8. Patil K. J., Khan E., 1982. Taxonomic studies on nematodes of Vidarbha region of Maharashtra, India. II. Two new species belonging to the family Nordiidae (Dorylaimida: Nematoda). Indian Journal of Nematology, 12: 47-52.

9. Saha M., Lai M., Singh M., 2002. Description of two new nematode species Geomonghystera auvillis n. sp. (Monhysterida: Monhysteridae) and Longidorella xesua n. sp. (Dorylaimida: Nordidae) from north India with a compendium of Geomonhystera spp. Annales plant protection of Science, 10(1): 121-127.

10. Siddiqi M. R., 1964. Studies on Discolaimus spp. (Nematoda: Dorylaimidae) from India. Zeitschrift für Zoologische Systematik and Evolutionsforschung, 2: 174-184.

11. Siddiqi M. R., 2007. Studies on the genus Longidorella Thorne (Nematoda: Dorylaimida) with descriptions of fifteen new species. International Journal of Nematology, 17: 63-90.

12. Suryawanshi M. V., 1971. Studies on the genus Longidorella Thorne, 1939 (Nematoda: Nordiidae) from Marathwada, India, with description to two new species. Marathwada University, Journal of Sciences, 10: 75-83. 


\title{
PHÁT HIÊN MỚI HAI LOÀI TUYẾN TRÙNG THUỘC HO NORDIIDAE (NEMATODA: DORYLAIMIDA) CHO KHU HÊ VIẸTT NAM Ở VƯờN QUỐC GIA CÚC PHƯƠNG
}

\author{
Nguyễn Thị Ánh Dương ${ }^{1}$, Vũ Thị Thanh Tâm ${ }^{1}$, Reyes Peña-Santiago ${ }^{2}$ \\ ${ }^{1}$ Viện Sinh thái và Tài nguyên sinh vật, Viện Hàn lâm KH \& CN Việt Nam \\ ${ }^{2}$ Đại học tổng hợp Jaén, Tây Ban Nha
}

\section{TÓM TÁT}

Tuyến trùng sống tự do trong đất họ Nordiidae là một trong những họ thuộc bộ Dorylaimida ít được biết đến nhất ở Việt Nam, cho đến nay, mới chỉ có 1 loài Actinolaimoides angolensis (Andrássy, 1963) Siddiqi, 1982 được phát hiện từ Vườn quốc gia Cúc Phương. Bài báo này ghi nhận thêm 2 loài tuyến trùng cho khu hệ Việt Nam là Longidorella xenura Khan \& Siddiqi, 1963 và Oriverutus parvus Ahmad \& Araki, 2002.

Loài Longidorella xenura Khan \& Siddiqi, 1963 có kích thước cơ thể nhỏ, $\mathrm{L}=0,72 \mathrm{~mm}$; vùng môi tròn và không tách biệt với đường viền cơ thể. Odontostyle dài, mảnh mai cong nhẹ hình cánh cung đặc trưng cho giống. Con cái có hệ sinh sản đôi didelphic-amphidelphic với hai nhánh phát triển đều nhau. Đuồi hình chóp kéo dài với mút đuôi tròn.

Loài Oriverutus parvus Ahmad \& Araki, 2002 có kích thước cơ thể nhỏ, $\mathrm{L}=0,64-0,68 \mathrm{~mm}$, vùng môi hình chữ nhật hơi tách biệt với đường viền của cơ thể và có phần phụ nhô cao,các môi hợp lại với nhau chứ không tạo dạng thùy đặc trưng của giống Oriverutus. Odontostyle ngắn, lumen rõ ràng, lố mở rộng. Con cái có hệ sinh sản đôi didelphic-amphidelphic với hai nhánh phát triển đều nhau. Đuôi hình chóp kéo dài và uốn cong về phía bụng với mút đuôi tròn.

Từ khóa: Dorylaimida, Nordiidae, ghi nhận mới, tuyến trùng, Cúc Phương, Việt Nam.

Ngày nhận bài: 8-1-2013 